\title{
Microwave-Induced Structural and Functional Injury of Hippocampal and PC12 Cells Is Accompanied by Abnormal Changes in the NMDAR-PSD95-CaMKII Pathway
}

\author{
Li-Feng Wang ${ }^{\text {a }}$ Li Wei $^{\mathrm{c}}$ Si-Mo Qiao ${ }^{\text {a }}$ Xiao-Na Gao ${ }^{a}$ Ya-Bing Gao ${ }^{a}$ \\ Shui-Ming Wang ${ }^{\mathrm{a}} \mathrm{Li}_{\mathrm{Zhao}}{ }^{\mathrm{a}} \mathrm{Ji}$ Dong $^{\mathrm{a}}$ Xin-Ping Xu ${ }^{\mathrm{a}}$ Hong-Mei Zhou ${ }^{\mathrm{b}}$ \\ Xiang-Jun $\mathrm{Hu}^{\mathrm{a}}$ Rui-Yun Peng ${ }^{\mathrm{a}}$ \\ Laboratory of axperimental Pathology and ${ }^{\mathrm{b}}$ Radiation Protection, Beijing Institute of Radiation Medicine, and \\ 'Department of Pathology, Beijing Tongren Hospital, Beijing, China
}

\section{Key Words}

Microwave · NMDARs · PSD95 · CaMKII · Synapsin I

\begin{abstract}
Recent studies have highlighted the important role of the postsynaptic NMDAR-PSD95-CaMKII pathway for synaptic transmission and related neuronal injury. Here, we tested changes in the components of this pathway upon microwave-induced neuronal structure and function impairments. Ultrastructural and functional changes were induced in hippocampal neurons of rats and in PC 12 cells exposed to microwave radiation. We detected abnormal protein and mRNA expression, as well as posttranslational modifications in the NMDAR-PSD95-CaMKII pathway and its associated components, such as synapsin I, following microwave radiation exposure of rats and $\mathrm{PC} 12$ cells. Thus, microwave radiation may induce neuronal injury via changes in the molecular organization of postsynaptic density and modulation of the biochemical cascade that potentiates synaptic transmission.

(c) 2015 S. Karger AG, Basel
\end{abstract}

() 2015 S. Karger AG, Basel

1015-2008/15/0825-0181\$39.50/0

\section{Introduction}

Microwave radiation is a type of nonionizing electromagnetic radiation with a frequency that ranges from 300 to $3 \times 10^{5} \mathrm{MHz}$. Research into the effects of microwave radiation on health has grown exponentially in line with its increased use in industry, commerce, medicine and for private purposes, especially for mobile telephone usage. Numerous in vivo and in vitro studies have been performed to investigate the biological consequences of microwave radiation on the nervous system and to assess its potential health risks [1-3]. It has been shown that microwaves alter cognitive function and induce neuronal injury, but little is known about how microwave radiation induces these impairments.

Recent studies on the molecular and cellular basis of synaptic maturation and plasticity brought us closer than ever to understand the mechanisms of cognitive

L.F.W. and L.W. contributed equally to this study and should be considered co-first authors.

\section{KARGER 125}

E-Mail karger@karger.com www.karger.com/pat
Rui-Yun Peng or Xiang-Jun Hu

Laboratory of Experimental Pathology

Beijing Institute of Radiation Medicine

27 Taiping Road, Beijing 100850 (China)

E-Mail pengry@ nic.bmi.ac.cn or xjhu2003@vip.sina.com 
function. The identification of regulatory mechanisms of glutamate (Glu) receptor trafficking is crucial to demonstrate these synaptic changes. These processes commonly activate calcium-permeable postsynaptic Nmethyl-D-aspartate receptors (NMDARs), i.e. heteromeric complexes that incorporate different subunits within a repertoire of three subtypes: NR1, NR2 (NR2AD) and NR3 (NR3A and NR3B) [4-6]. Upon stimulation, different patterns of NMDAR activation can lead to long-term potentiation (LTP) or long-term depression (LTD) of synaptic strength via selectively binding of signaling scaffold postsynaptic density proteins, such as PSD95 [7], and activation of calcium-activated enzymes, such as calcium/calmodulin-dependent protein kinase II (CaMKII) [8-12], to sustain the molecular organization of postsynaptic density and initiate the biochemical cascade that potentiates synaptic transmission [13, 14]. Thus, disruptions in this NMDAR-PSD95-CaMKII pathway can lead to loss of synaptic function and other severe neuropathological conditions.

In the present study, we demonstrate that abnormalities in the NMDAR-PSD95-CaMKII pathway upon exposure of PC12 cells and rats to microwave radiation were correlated to abnormal changes in the ultrastructure and synaptic transmission. We also determined the expression and phosphorylation of synapsin I, which could serve as a link between synaptic transmission and the NMDAR-PSD95-CaMKII pathway in PC12 cells. These findings may help to elucidate both the mechanisms of synaptic maturation and plasticity, and microwave-induced neuron injury.

\section{Materials and Methods}

\section{Ethics Statement}

All animal work was conducted according to relevant national and international guidelines. The study was approved by the Beijing Institute of Radiation Medicine Animal Care and Use Committee. It was carried out in accordance with the National Institute of Health Guide for the Care and Use of Laboratory Animals.

\section{Cell Culture}

PC12 cells were cultured at $37^{\circ} \mathrm{C}$ and $5 \% \mathrm{CO}_{2}$ in Dulbecco's modified Eagle's medium (DMEM) supplemented with $5 \%$ fetal bovine serum, $10 \%$ horse serum and $100 \mathrm{U} / \mathrm{ml}$ penicillin and streptomycin. Cells were plated in 6-well tissue culture plates coated with poly-D-lysine at a density of $2-5 \times 10^{4}$ cells $/ \mathrm{cm}^{2}$. Nerve growth factor containing medium $(2.5 \mathrm{~s}$ at $50 \mathrm{ng} / \mathrm{ml}$; Chemicon, Temecula, Calif., USA) was added to the cultures on the 2 nd day of plating. Cells were treated with nerve growth factor for 5-7 days prior to the experiment, and media were changed twice weekly.
Experimental Groups and Microwave Exposure Procedure

Sixty male Wistar rats weighing 160-200 g were housed at a constant temperature $\left(22 \pm 1^{\circ} \mathrm{C}\right)$ and relative humidity $(60 \%)$ under a regular dark-light schedule (lights on from 7 a.m. to 7 p.m.). The rats in the exposure group (comprising 30 rats) were placed in individual polypropylene cages where they received microwave exposure for $5 \mathrm{~min}$; the mean power density was $10 \mathrm{~mW} / \mathrm{cm}^{2}$. As described previously [15], the microwave source, a klystron amplifier model JD 2000 (Vacuum Electronics Research Institute), was capable of generating pulsed microwaves at a frequency of 2.856 $\mathrm{GHz}$. Microwave energy was transmitted by rectangular waveguide and $\mathrm{A} 16-\mathrm{dB}$ standard-gain horn antenna to an electromagnetic shield chamber $(7 \times 6.5 \times 4 \mathrm{~m})$. Sham-treated controls (comprising the remaining 30 rats) were also placed in polypropylene cages for $5 \mathrm{~min}$, but did not receive microwave exposure. The rectal temperature of all rats was measured before and after microwave exposure.

PC12 cells were placed in 6-well tissue culture plates. The cells from the exposed group received microwave radiation for $5 \mathrm{~min}$ with a mean power density of $30 \mathrm{~mW} / \mathrm{cm}^{2}$. The cells from the sham-treated control group were subjected to the same conditions, but the microwave generators were not energized. The supernatant temperature was measured before and after microwave radiation using an optic fiber thermometer 3300 (Luxtron Corp., Santa Clara, Calif., USA).

\section{Ultrastructure and Quantitative Assessments}

Animals were anesthetized with sodium pentobarbital (50 mg/ kg i.p.) and decapitated $6 \mathrm{~h}$ and 1, 7, 14 and 28 days after microwave exposure. The brains of the rats were quickly removed and the hippocampus was isolated. Tissue $\left(1 \mathrm{~mm}^{3}\right.$ in size $)$ was taken from the CA3 region of the hippocampus of rats $6 \mathrm{~h}$ and 7 days following radiation. PC12 cells $\left(1-5 \times 10^{6}\right)$ were harvested by scraping and subjected to centrifugation at $120 \mathrm{~g}$ for $10 \mathrm{~min} 6 \mathrm{~h}$ after radiation, and then immediately fixed in $3 \%$ paraformaldehyde and $1 \%$ glutaraldehyde in $0.1 \mathrm{M}$ phosphate buffer for $2 \mathrm{~h}$. The fractions were rinsed, postfixed with $1 \% \mathrm{OsO}_{4}$, dehydrated and then embedded in paraffin. Routine mounting and uranyl/lead staining were performed for electron microscopy (EM; PhilipCM120; Philips, Amsterdam, the Netherlands). Each specimen was observed on two copper grids that slowly shifted to the lower right, during which 10 micrographs at a magnification of $\times 280,000$ were taken. The length of the active zone, thickness of postsynaptic density and the curvature of synapses in the scanned images were measured using a CMIAS-II image analyzer (Beijing University of Aeronautics and Astronautics, Beijing, China).

\section{Amino Acid Content and Release}

Six hours, 1 and 7 days after microwave exposure, tissue samples from the CA3 region of rat hippocampi were isolated and homogenized (1:100) in ice-cold $10 \%$ sulfonic salicylate. The homogenates were centrifuged at $27,000 \mathrm{~g}$ for $20 \mathrm{~min}$ at $4^{\circ} \mathrm{C}$. The pellets were discarded and the supernatants were stored at $-20^{\circ} \mathrm{C}$. Six hours after microwave exposure, PC12 cells were incubated in DMEM with $2 \mathrm{M} \mathrm{KHCO}_{3}$ for $2 \mathrm{~min}$, then the culture medium was collected and centrifuged at $120 \mathrm{~g}$ for $10 \mathrm{~min}$. The supernatants were centrifuged at $3,000 \mathrm{~g}$ for $15 \mathrm{~min}$ after addition of $10 \%$ sulfonic salicylate $(3: 2)$. The supernatants were also stored at $-20^{\circ} \mathrm{C}$. The samples of the hippocampal supernatants and PC12 cells were subjected to high-performance liquid chromatography, respec- 
tively (Hp1050 pump, Hp1046A fluorometric detector; Hewlett Packard, Palo Alto, Calif., USA), and the contents and release of amino acids were determined.

\section{Immunohistochemistry}

To dually localize NMDARs and PSD95 within cell types and subcellular areas, the other halves of the brains were fixed, dehydrated, cleared, infiltrated and embedded in wax $6 \mathrm{~h}$, and 1, 7, 14 and 28 days after microwave exposure. Paraffin-embedded brains were cut into $5-\mu \mathrm{m}$ coronal sections and processed immunohistochemically by dewaxing and dehydrating. PC12 cells growing on poly-Dlysine-coated glass coverslips in 6-well tissue culture plates were subjected to the experiments, and they were tested $6 \mathrm{~h}$ after microwave exposure or no exposure (controls). Sections or coverslips were washed in $0.1 \mathrm{M}$ PBS and incubated with either NR1, NR2A, NR2B (1:200, polyclonal rabbit IgG; Santa Cruz, Santa Cruz, Calif., USA), PSD95 (1:200, monoclonal mouse IgG; Sigma, St. Louis, Mo., USA), p-CaMKII (1:200, polyclonal goat IgG; Santa Cruz), synapsin I (1:100, polyclonal goat Ig; Santa Cruz) or p-synapsin I (Ser ${ }^{62 / 67}$, Ser ${ }^{553}$; $1: 100$, polyclonal rabbit IgG; Santa Cruz) primary antibody overnight. This was followed by incubation in ABC kit (Zhongshan Jinqiao Biotechnology, Beijing, China) for tissues or 1\% BSA with secondary antibodies conjugated either to Alexa Fluor 568 or Alexa Fluor 488 (1:250; Invitrogen, Carlsbad, Calif., USA) for PC12 cells. For the hippocampus, immunostaining was visualized with diaminobenzidine using the peroxidase substrate kit (Zhongshan Jinqiao Biotechnology). Sections were then examined with a photomicroscope or laser scanning confocal microscope (Radiance $2100^{\mathrm{TM}}$; BioRad, Hercules, Calif., USA). For double-label experiments, scans at different wavelengths were digitally merged. The integral optical density (IOD) or integrated density value (IDV) of images was measured using a CMIAS-II image analyzer.

\section{Immunoblotting and Co-Immunoprecipitation Assays}

Six hours after exposure, PC12 cells were transferred to ice-cold buffer containing $20 \mathrm{~mm}$ EDTA, $0.1 \mathrm{~mm}$ sodium orthovanadate, $20 \mu \mathrm{g} / \mathrm{ml}$ aprotinin, $10 \mu \mathrm{g} / \mathrm{ml}$ leupeptin and $0.1 \mathrm{mg} / \mathrm{ml}$ phenylmethylsulfonyl fluoride. Protein concentrations were determined using the BCA protein assay (Pierce, Rockford, Ill., USA). Homogenates were mixed at a ratio of 3:2 with sample buffer containing 4\% SDS, $250 \mathrm{~mm}$ Tris, $3 \mathrm{~mm}$ EDTA, 20\% glycerol, 5\% $\beta$-mercaptoethanol and $0.05 \%$ bromophenol blue $(\mathrm{pH} 8.0)$ at $95^{\circ} \mathrm{C}$ for $10 \mathrm{~min}$. For each condition, $25 \mu \mathrm{g}$ of protein were loaded into each well on $10 \%$ SDS-polyacrylamide gel. After separation by electrophoresis, protein samples were electrotransferred onto a nitrocellulose membrane in transfer buffer $(25 \mathrm{mM}$ Tris/ $192 \mathrm{mM}$ glycine (Gly)/0.02\% SDS/20\% methanol) for $180 \mathrm{~min}$ at a constant current $(26 \mathrm{~mA})$. Additional protein binding sites on the nitrocellulose membrane were saturated by incubation in $10 \mathrm{mM}$ PBS with $0.1 \%$ Tween-20 (PBST, pH 7.4) containing 10\% dry milk powder for $1 \mathrm{~h}$ at room temperature. After a short wash with PBST, blots were incubated with antiserum to either NR2B (1:500, polyclonal rabbit IgG; Santa Cruz), PSD95 (1:500, monoclonal mouse IgG; Sigma), p-CaMKII (1:500, polyclonal goat IgG, Santa Cruz), synapsin I (1:500, polyclonal goat Ig; Santa Cruz) or p-synapsin I (Ser ${ }^{62 / 67}$, Ser $^{553} ; 1: 500$, polyclonal rabbit IgG; Santa Cruz) overnight at $4^{\circ} \mathrm{C}$. After rinsing three times with PBST, membranes were incubated with an anti-rabbit or anti-mouse HRP-conjugated secondary antibody (1:2,000, Zhongshanjinqiao) and HRPconjugated monoclonal mouse IgG specific for GAPDH $(1: 10,000$;
Nanjingjiancheng) for $1 \mathrm{~h}$ at room temperature. Bands were developed on autoradiographic film using an enhanced chemiluminescence kit (Pierce). The film signals were scanned using a highresolution scanner, and the IOD of the scanned images was measured using a CMIAS-II image analyzer.

Three hundred micrograms of protein were diluted in $250 \mu \mathrm{l}$ of buffer containing $20 \mathrm{mM}$ EDTA, $0.1 \mathrm{mM}$ sodium orthovanadate, $20 \mu \mathrm{g} / \mathrm{ml}$ aprotinin, $10 \mu \mathrm{g} / \mathrm{ml}$ leupeptin and $0.1 \mathrm{mg} / \mathrm{ml}$ phenylmethylsulfonyl fluoride. After incubating the solubilized homogenates with a phosphotyrosine (Invitrogen), PSD95 antibody conjugated to protein A-agarose (Santa Cruz) overnight at $4^{\circ} \mathrm{C}$, they were centrifuged at $2,000 \mathrm{~g}$ for $5 \mathrm{~min}$ at $4^{\circ} \mathrm{C}$. The supernatants were discarded, and the pellets were washed with buffer $(500 \mathrm{mM} \mathrm{NaCl}$, $10 \mathrm{mM}$ Tris and $2 \mathrm{mM}$ EDTA, pH 7.5) four times and then centrifuged. The pellets were mixed at a 1:1 ratio with $20 \mu \mathrm{l}$ of the above buffer and $20 \mu \mathrm{l}$ of sample buffer containing $4 \%$ SDS, $250 \mathrm{~mm}$ Tris, 3 mM EDTA, $20 \%$ glycerol, $5 \% \beta$-mercaptoethanol and $0.05 \%$ bro-

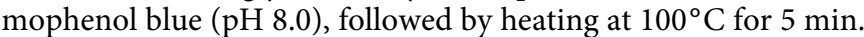
After cooling the sample, it was centrifuged at $3,000 \mathrm{~g}$ for $10 \mathrm{~min}$ at $4{ }^{\circ} \mathrm{C}$, and the supernatants were analyzed by SDS-PAGE. Proteins were resolved by $10 \%$ SDS-PAGE and electrotransferred to $0.2-\mathrm{mm}$-thick nitrocellulose sheets for immunoblot analysis using NR2B or p-CaMKII antibodies.

\section{Reverse Transcription Polymerase Chain Reaction}

To determine NR2B and PSD95 mRNA levels, total RNA of PC12 cells was isolated using a Qiagen RNeasy Mini Kit (Qiagen, Valencia, Calif., USA) and quantified using a spectrophotometer (GeneQuant pro; Amersham, Piscataway, N.J., USA) $6 \mathrm{~h}$ after microwave exposure or no exposure (controls). The Qiagen RT reagent kit (Qiagen) with random hexamer primers was used to reverse-transcribe $500 \mathrm{ng}$ of total RNA to cDNA. Primers (Aoke, Beijing, China) were mixed with $2 \times$ Master mix (Qiagen); then $0.5 \mu \mathrm{l}$ cDNA were added to a $20-\mu \mathrm{l}$ total volume. Polymerase chain reaction (PCR) was performed as follows: $95^{\circ} \mathrm{C}$ for $5 \mathrm{~min}$, followed by 35 denaturing cycles at $94^{\circ} \mathrm{C}$ for $30 \mathrm{~s}$, annealing at $56^{\circ} \mathrm{C}$ for $45 \mathrm{~s}$, and extension cycles at $72^{\circ} \mathrm{C}$ for $45 \mathrm{~s}$, then a final extension cycle at $72^{\circ} \mathrm{C}$ for $5 \mathrm{~min}$. Reaction specificity was confirmed by gel electrophoresis of RT-PCR products in order to identify bands of expected amplicon size: 274 bp for NR2B, 284 bp for PSD95 and 512 $\mathrm{bp}$ for $\beta$-actin. The sequences used were as follows: NR2B, $5^{\prime}$-AGA GCT CCT TTG CCA ACA AGT-3' (forward) and $5^{\prime}$-ATG TCC TTC TGG AAA CGA CCT-3' (reverse); PSD95 5'-AAG GAC ATC CAG GCA CAC AAG-3' (forward) and $5^{\prime}$-ACG ATG GCT GAG AAG CAC TCT- $3^{\prime}$ (reverse), and $\beta$-actin $5^{\prime}$-CTG TGC CCA TCT ATG AGG GTT AC-3' (forward) and $5^{\prime}$-AAT CCA CAC AGA GTA CTT GCG CT-3' (reverse). The PCR results were obtained using a gel imaging analysis system (FluorChem FC2; Alpha Innotech, San Leandro, Calif., USA), and the IOD of scanned images was measured using a CMIAS-II image analyzer.

\section{Electrophoretic Mobility Shift Assay}

Six hours and 1 day after microwave exposure, PC12 cells were homogenized in $10 \mathrm{~mm}$ sodium HEPES ( $\mathrm{pH} 7.9$ ) containing $0.75 \mathrm{~mm}$ spermidine, $1.5 \mathrm{mM}$ spermine, $10 \mathrm{mM} \mathrm{KCl}, 1 \mathrm{mM}$ DTT, $0.1 \mathrm{mM}$ EDTA, $0.1 \mathrm{mM}$ EGTA, $5 \mathrm{mM}$ dithiothreitol, phosphatase inhibitors (10 mM sodium $\beta$-glycerophosphate and $1 \mathrm{mM}$ sodium orthovanadate) and $1 \mu \mathrm{g} / \mathrm{ml}$ of each protease inhibitor (phenylmethane sulfonyl fluoride, benzamidine, leupeptin and aprotinin). After the addition of Nonidet P-40 at a final concentration of $0.5 \%$, the homogenates 
were centrifuged at 27,000 $\mathrm{g}$ for $5 \mathrm{~min}$ to pellet a nucleus-containing fraction. The pellets were suspended in $50 \mathrm{mM}$ Tris- $\mathrm{HCl}$ (pH 7.5) containing $20 \%$ glycerol, $10 \%$ sucrose, $420 \mathrm{mM} \mathrm{KCl}, 5 \mathrm{mM} \mathrm{MgCl}_{2}$, $0.1 \mathrm{mM}$ EDTA, $0.2 \mathrm{mM}$ EGTA and the above-mentioned phosphatase and protease inhibitors, and kept on ice for $30 \mathrm{~min}$. The suspensions were then centrifuged at $27,000 \mathrm{~g}$ for $5 \mathrm{~min}$, and the supernatant nuclear extracts were stored at $-80^{\circ} \mathrm{C}$ until assayed.

Oligonucleotides containing the cyclic AMP response element binding protein (CREB) binding sequence, $5^{\prime}$-AGA GAT TGC CTG ACG TCA GAG AGC TAG-3', and its complementary sequence, were annealed as a probe for the electrophoretic mobility shift assay (EMSA, Pierce). The probe was labeled with biotin (Invitrogen). A $6 \%$ polyacrylamide gel in $0.5 \times$ TBE (Tris, boric acid and EDTA) was prepared and pre-electrophoresed for $30 \mathrm{~min}$ (100 $\mathrm{V})$. Then, $20 \mu \mathrm{l}$ of each sample were loaded onto the polyacrylamide gel and electrophoresed for about $60 \mathrm{~min}(100 \mathrm{~V})$. After separation by electrophoresis, samples were electrotransferred onto nylon membrane in a transfer buffer $(0.5 \times \mathrm{TBE})$ for $60 \mathrm{~min}$ at a constant current $(380 \mathrm{~mA})$. When the transfer was completed, the membrane was cross-linked at a commercial UV light crosslinking instrument for $30 \mathrm{~min}$. The membrane was treated with $66.7 \mu \mathrm{l}$ stabilized streptavidin-horseradish peroxidase conjugate for $15 \mathrm{~min}$ and incubated in $30 \mathrm{ml}$ of substrate equilibration buffer for $5 \mathrm{~min}$ with gentle shaking. Bands were developed on autoradiographic film by chemiluminescence using an ECL kit and exposed to an appropriately equipped CCD camera for 2-5 min.

\section{Statistical Analysis}

Results are expressed as means \pm SEM, and differences were analyzed with one-way ANOVA using SPSS (version 11.1). Differences at the $\mathrm{p}<0.05$ level were considered significant.

\section{Results}

Hippocampal Neuronal Ultrastructure Was Damaged and Amino Acid Contents Were Decreased in Rats following Microwave Radiation Treatment

The effects of microwave radiation on the hippocampal ultrastructure were examined using EM and quantitatively analyzed $6 \mathrm{~h}$ and 7 days after microwave exposure $\left(10 \mathrm{~mW} / \mathrm{cm}^{2}\right)$. Compared with the sham-treated controls

Fig. 1. Effects of $10 \mathrm{~mW} / \mathrm{cm}^{2}$ microwaves on the hippocampal ultrastructure and amino acid contents of rats. a Representative image of normal neuronal structure with uniformly distributed nuclear chromatin, mitochondria, rough-surfaced endoplasmic reticulum, ribosome-rich cytoplasm and myelin sheath-like concentric circles. Scale bar $=1 \mu \mathrm{m}$. b Representative image of abnormal neuronal ultrastructure $6 \mathrm{~h}$ after microwave exposure, with mitochondrial swelling and ridge rupture, even cavitation, rough endoplasmic reticulum degranulation and swelling, broadening of the nuclear membrane gap in neurons, concentration and margination of chromatin, and a decrease in organelles in neuroglia. Scale bar $=500 \mathrm{~nm}$. c Normal synaptic structure (fig. 1a), the radiation-treated rat hippocampal neurons showed cytoplasmic relaxation, mitochondrial swelling and ridge rupture, even cavitation, rough endoplasmic reticulum degranulation and swelling, broadening of the nuclear membrane gap, and concentration and margination of the chromatin $6 \mathrm{~h}$ after radiation (fig. 1b). Microwave exposure $\left(10 \mathrm{~mW} / \mathrm{cm}^{2}\right)$ also induced abnormal synaptic structures and plasticity, such as deposits or evacuation of synapse vesicles, elongation of the active zone $(\mathrm{p}<0.01)$, broadening of the synaptic cleft $(\mathrm{p}<0.05)$, increased PSD thickness $(\mathrm{p}<0.01)$ and synapse perforation (fig. 1d) at this time point. Semi-quantified data are shown in figure 1e, f. After 7 days, deposits of synapse vesicles and widening of the perivascular space were aggravated, but the degree of injury to the hippocampal neurons was alleviated (data not shown). Thus, microwave radiation-induced hippocampus damage mostly affected the synaptic structure and plasticity.

Next, we assessed the amino acid contents to estimate synaptic maintenance and remodeling $6 \mathrm{~h}$, and 1 or 7 days after radiation. The contents of asparagine (Asp) and Gly were decreased (Asp: $\mathrm{p}<0.05$; Gly: $\mathrm{p}<0.01$ ) in the hippocampus $6 \mathrm{~h}$ after microwave exposure, but returned to normal 1 and 7 days after radiation (fig. 1g). The decrease in Glu was significant $6 \mathrm{~h}$, and 1 and 7 days after radiation $(\mathrm{p}<$ 0.01 ), while no significant changes in GABA were observed. Amino acid metabolism was disturbed following microwave radiation. These results suggested that the decrease in hippocampal content of Glu, the main excitatory amino acid in the brain, might play an important role in the neuronal injury induced by microwave radiation $\left(10 \mathrm{~mW} / \mathrm{cm}^{2}\right)$.

\section{PC12 Ultrastructure Was Damaged and Amino \\ Acid Release Was Decreased following Microwave Radiation}

The ultrastructure of $\mathrm{PC} 12$ cells and the release of amino acids were assessed $6 \mathrm{~h}$ after microwave exposure (30

showing that the synaptic vesicles are evenly distributed and the synaptic cleft (arrowhead) is clear. Scale bar $=200 \mathrm{~nm}$. d A representative image of abnormal synaptic structure $6 \mathrm{~h}$ after radiation with the synaptic cleft (arrowhead), large deposits of synaptic vesicles and increased PSD thickness. Scale bar $=200 \mathrm{~nm}$. e Semi-quantified data for width of synaptic cleft and thickness of postsynaptic density of the hippocampus. $f$ Semi-quantified data for the length of the active zone of the hippocampus. Values represent means \pm SEM of 10 fields in 3 animals. g Amino acid content in the hippocampus. Values represent means \pm SEM of 5 animals. ${ }^{*} \mathrm{p}<0.05,{ }^{* *} \mathrm{p}<0.01$ vs. corresponding sham-treated controls. 

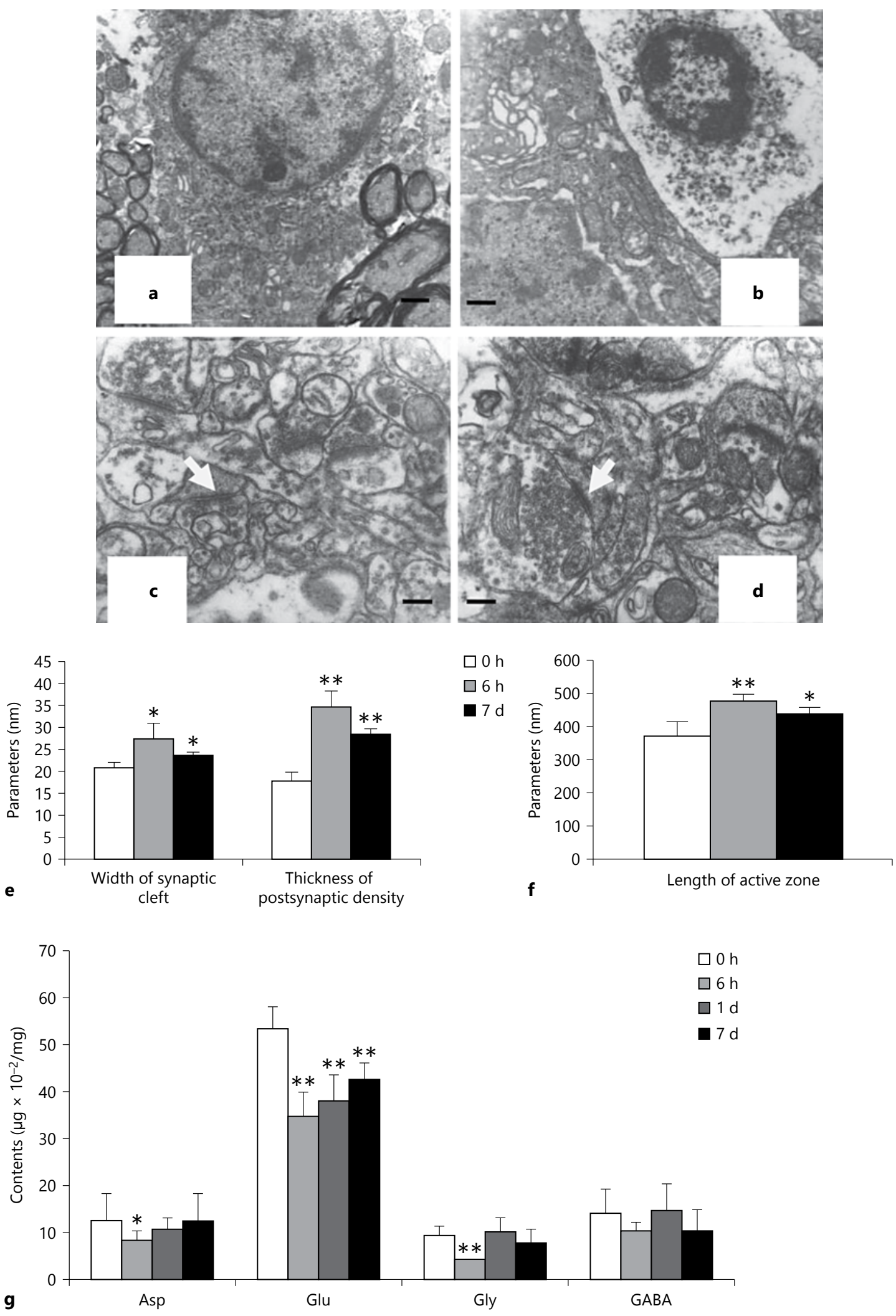

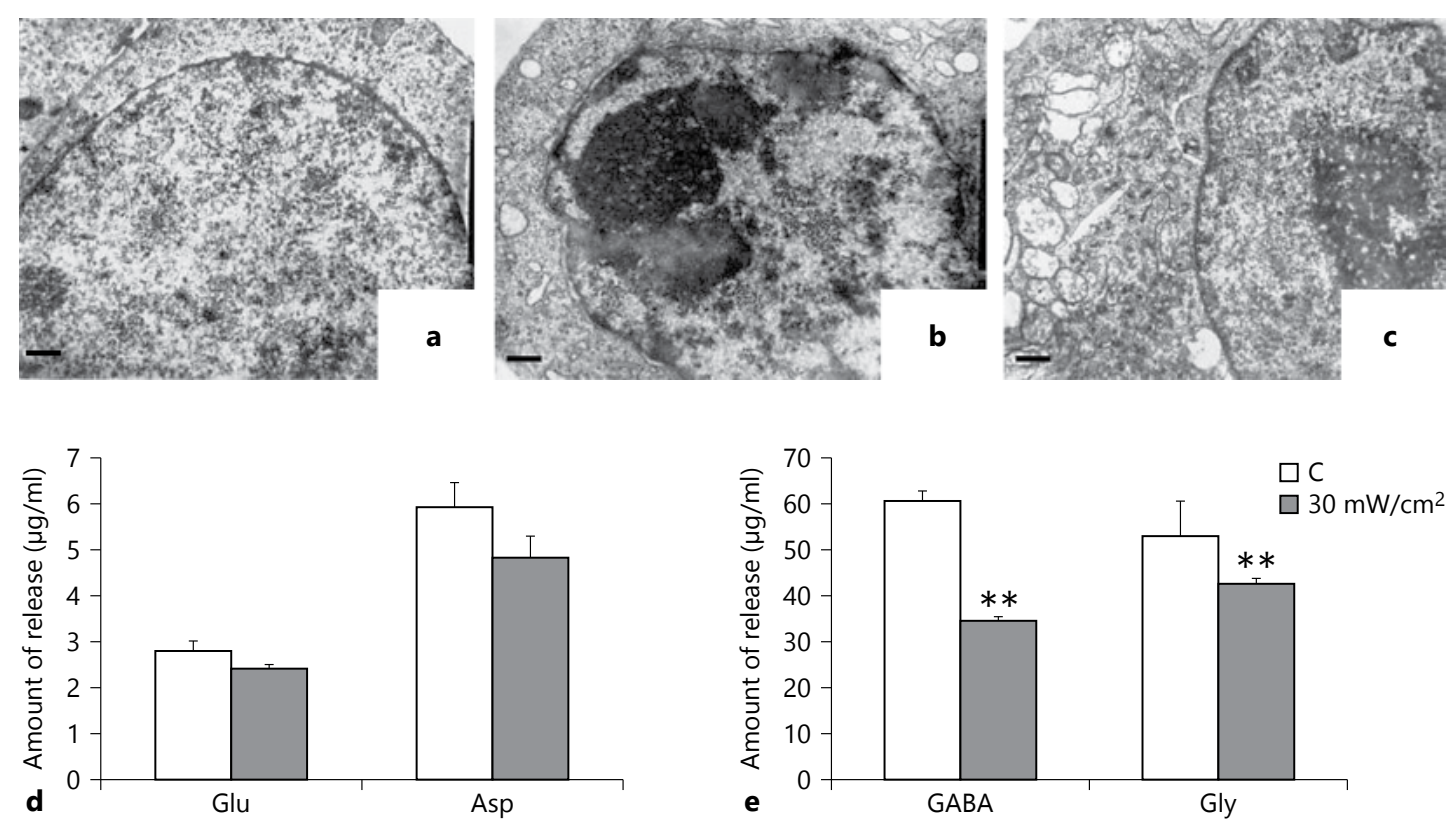

Fig. 2. Effects of $30 \mathrm{~mW} / \mathrm{cm}^{2}$ microwaves on the ultrastructure of PC12 cells and the release of amino acids. a A representative image of the normal PC12 cell structure with uniformly distributed nuclear chromatin, normal mitochondria and rough-surfaced endoplasmic reticulum in the cytoplasm. b A representative image of abnormal PC12 cell structure $6 \mathrm{~h}$ after radiation, with abnormal nuclear shape, broadening of the nuclear membrane gap, concentration and margination of the chromatin and rough endoplasmic reticulum degranulation and swelling. c Representative image of abnormal PC12 cell structure after radiation showing mitochondrial swelling and cavitation and rough endoplasmic reticulum degranulation and swelling. a-c Scale bar $=500 \mathrm{~nm}$. d Release of Glu and Asp $6 \mathrm{~h}$ after $30 \mathrm{~mW} / \mathrm{cm}^{2}$ microwave exposure. e Release of GABA and Gly $6 \mathrm{~h}$ after $30 \mathrm{~mW} / \mathrm{cm}^{2}$ microwave exposure. Each value represents the mean \pm SEM of 5 samples. ${ }^{* *} \mathrm{p}<0.01$ vs. corresponding sham-treated controls $(\mathrm{C})$.
$\mathrm{mW} / \mathrm{cm}^{2}$ ) or mock treatment. Compared with shamtreated controls (fig. 2a), exposed PC12 cells had abnormal nuclear shapes, broadening of the nuclear membrane gap, concentration and margination of the chromatin, mitochondrial swelling and cavitation, and rough endoplasmic reticulum degranulation and swelling (fig. 2b, c). The release of GABA and Gly was significantly decreased $(\mathrm{p}<0.01)$ in PC12 cells $6 \mathrm{~h}$ after radiation (fig. $2 \mathrm{e}$ ), while Asp and Glu levels were not changed (fig. 2d). The structure was impaired and amino acid secretion was inhibited in PC12 cells following microwave radiation treatment with $30 \mathrm{~mW} / \mathrm{cm}^{2}$.

\section{Abnormal Expression of NMDAR-PSD95-CaMKII Signal Transduction Molecules following Microwave Radiation}

The expression levels of NMDARs and PSD95 in rat hippocampal neurons were detected by immunochemistry $6 \mathrm{~h}$, and $1,7,14$ and 28 days following microwave exposure $\left(10 \mathrm{~mW} / \mathrm{cm}^{2}\right)$. In the sham-treated group, NR1, NR2A, NR2B and PSD95 were weakly expressed in the cytoplasm of hippocampal neurons (fig. 3a, c, e, g). Expression of NR1 was increased $6 \mathrm{~h}$ to 14 days following exposure, while that of NR2A increased after 1-14 days, NR2B increased from $6 \mathrm{~h}$ to 7 days, and PSD 95 increased after 1-7 days (fig. 3b, d, f, h). Semi-quantitative analysis showed that NR1, NR2A, NR2B and PSD95 protein expression peaked 1 day following exposure and remained significantly increased for at least 7 days (fig. 3i-l, respectively). These results suggested that the NMDAR-PSD95CaMKII pathway was activated in the hippocampus after microwave radiation.

Next, we examined the changes in the NR2B-PSD95CaMKII pathway in radiation-exposed PC12 cells. We first determined mRNA levels of the structural proteins, NR2B and PSD95, 3, 6 and $9 \mathrm{~h}$, and 1 and 2 days after microwave exposure. RT-PCR analysis demonstrated that NR2B mRNA was increased after 6 and 24 h, PSD95 mRNA was decreased after $6 \mathrm{~h}$, and then increased from $9 \mathrm{~h}$ to 2 days ( $\mathrm{p}<0.05$ and $\mathrm{p}<0.01$, respectively; fig. 4 ) following microwave radiation. The expression levels of NR2B, PSD95 and p-CaMKII, the co-localization of 


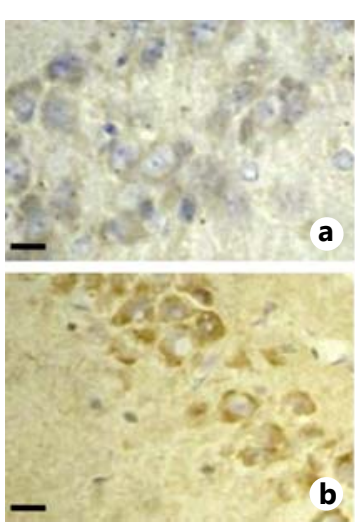

a
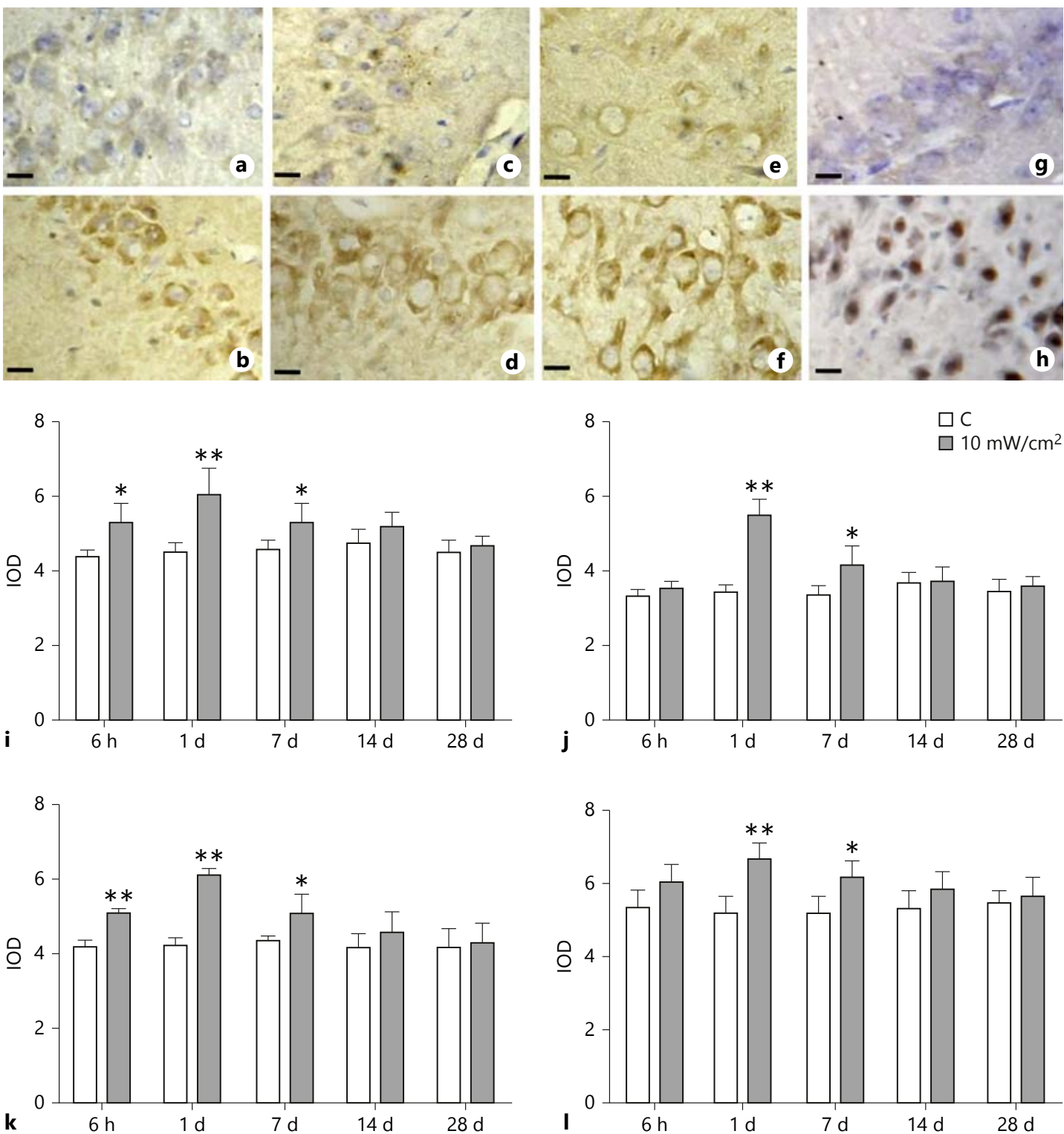

$\square \mathrm{C}$

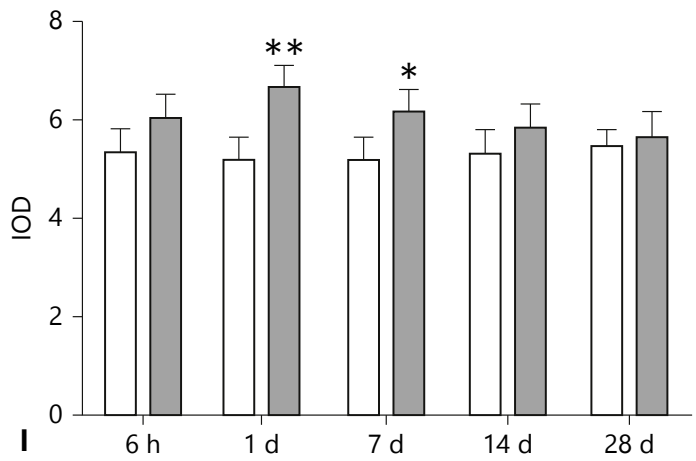

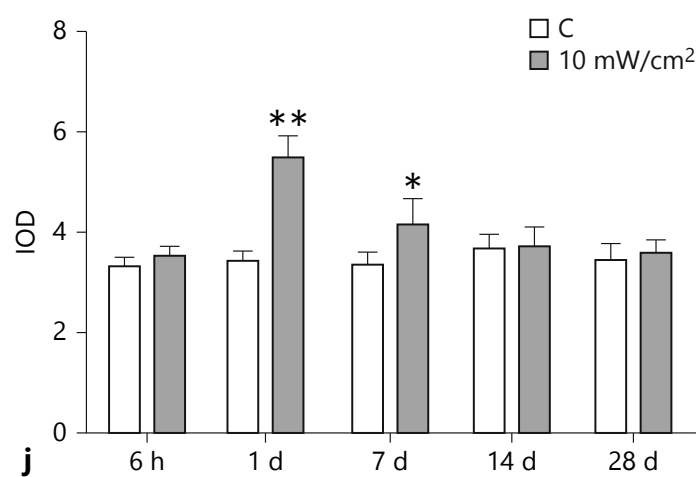

Fig. 3. Effects of $10 \mathrm{~mW} / \mathrm{cm}^{2}$ microwaves on the expression levels of NMDARs and PSD95 in the hippocampi of rats. $\mathbf{a}-\mathbf{h}$ Immunohistochemistry images are shown. $\mathrm{d}=$ Day. Scale bar $=10 \mu \mathrm{m}$. a, $\mathbf{c}, \mathbf{e}, \mathbf{g}$ Weak expression of NR1 (a), NR2A (c), NR2B (e) and PSD95 (g) was shown as light brown in the cytoplasm of hippocampal neurons from the sham-treated group. b, d, f Strong expression of NR1 (b), NR2A (d)and NR2B (f) was shown as dark brown in the cytoplasm of hip- pocampal neurons from the microwave-exposed group ( 1 day after exposure). $\mathbf{h}$ A representative image of strong expression of PSD95 in both cytoplasm and nuclei of hippocampal neurons 1 day after microwave exposure. See online version for colors. i-I Semi-quantified data for NR1, NR2A, NR2B and PSD95 expression, respectively. Values represent the mean \pm SEM of 10 fields for 5 animals. ${ }^{*} \mathrm{p}<0.05$, ${ }^{* *} \mathrm{p}<0.01$, vs. corresponding sham-treated controls $(\mathrm{C})$.
NR2B and PSD95, PSD95 and p-CaMKII in PC12 cells were detected by immunofluorescence and immunoblots $6 \mathrm{~h}$ after microwave exposure. In the sham-treated group, NR2B, PSD95 and p-CaMKII were positively expressed in the cytoplasm of PC12 cells. The expression levels of
NR2B, PSD95 and p-CaMKII, and co-localization of NR2B and PSD95, PSD95 and p-CaMKII, all decreased following exposure (fig. 5). These results showed that the expression of NR2B, PSD95 and p-CaMKII were inhibited, as were interactions between NR2B and PSD95, and 
Fig. 4. Effects of $30 \mathrm{~mW} / \mathrm{cm}^{2}$ microwaves on NR2B and PSD95 mRNA expression in PC12 cells. a Representative images of NR2B, PSD95 and $\beta$-actin mRNA by RTPCR. $\mathrm{M}=$ DNA marker $(\mathrm{D} 2000) ; 1=$ mRNA in sham-treated controls; $2,3,4,5$, $6=$ mRNA at 3, 6 and 9 h, 1 day, 2 days after microwave exposure, respectively. b, c Semi-quantified data for mRNA expression of NR2B (b) and PSD95 (c). Values represent the mean \pm SEM of 3 samples. * $\mathrm{p}<0.05,{ }^{* *} \mathrm{p}<0.01$, vs. corresponding sham-treated group.

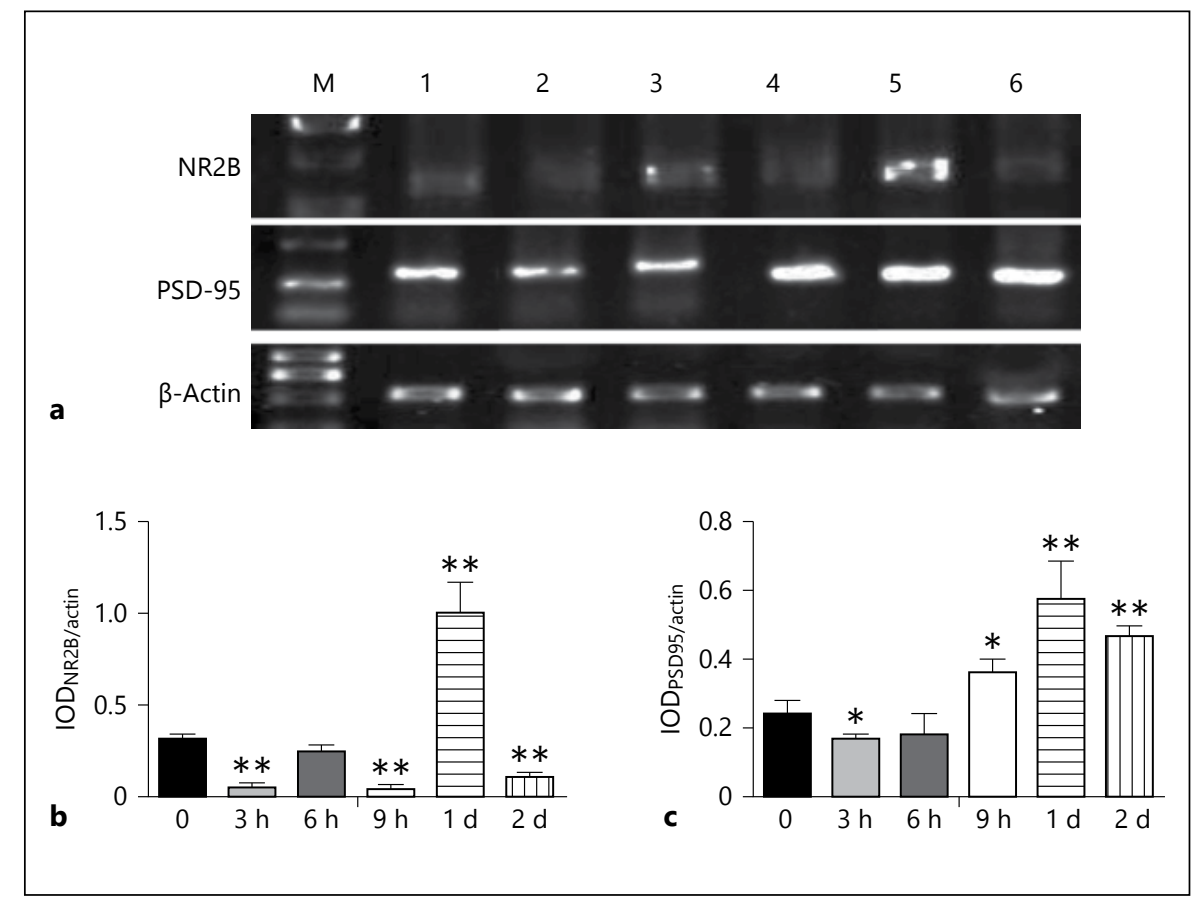

between PSD95 and p-CaMKII following microwave radiation $\left(30 \mathrm{~mW} / \mathrm{cm}^{2}\right)$.

Then the activity of CREB, which was one of the downstream transcription factors of the NMDAR-PSD95CaMKII pathway, was detected by DNA binding mobility shift assays in PC12 cells 6 and $24 \mathrm{~h}$ after microwave radiation. The active transcription factor can form a combined band with free probes. In the sham-treated group, the CREB-combined band was found. However, the band was reduced 1 day after exposure (fig. 6). This could result in decreased binding activity of CREB with DNA following microwave radiation $\left(30 \mathrm{~mW} / \mathrm{cm}^{2}\right)$.

\section{Abnormal Expression and Phosphorylation of Synapsin I in PC12 Cells following Microwave Radiation}

The expression and phosphorylation of synapsin I, which may be a liner between synaptic transmission and the NMDAR-PSD95-CaMKII pathway in PC12 cells, were detected by immunofluorescence and immunoblotting $6 \mathrm{~h}$ after microwave exposure $\left(30 \mathrm{~mW} / \mathrm{cm}^{2}\right)$. In the sham-treated group, synapsin I and p-synapsin I ( $\operatorname{Ser}^{62 / 67}$ and $\mathrm{Ser}^{553}$ ) were positively expressed in the cytoplasm of PC12 cells. Expression levels of synapsin I and p-synapsin I $\left(\operatorname{Ser}^{553}\right)$ were decreased $(\mathrm{p}<0.01)$, and expression of $\mathrm{p}$ synapsin I $\left(\mathrm{Ser}^{62 / 67}\right)$ was increased $(\mathrm{p}<0.01$; fig. 7$)$ after microwave exposure. These results showed that the ex- pression of synapsin I was inhibited, and the phosphorylation of synapsin I was altered at different sites following microwave radiation $\left(30 \mathrm{~mW} / \mathrm{cm}^{2}\right)$ depending on the different upstream kinases.

\section{Discussion}

Microwave Radiation May Induce Abnormal Synaptic Transmission in Hippocampal and PC12 Cells

Studies have shown that exposure to microwaves could result in injury to the brain structure, although studies have focused mainly on thermal effects. For example, immediately after and $2 \mathrm{~h}$ following $2.4 \mathrm{GHz}$, specific absorption rate (SAR) $5 \mathrm{~W} / \mathrm{g}$ radiation, certain disorders have been revealed in the microcirculation and reactive changes can occur in the mitochondria in perikaryons, axons, dendrites, neuronal synapses and gliocytes. In synapses, together with mitochondrial lesions, synaptic complexes underwent destruction and osmiophilic substance accumulated in the subsynaptic zone along the whole length of the contact [16-18]. They suggest that this is associated with the immediate heat effect of microwave radiation on the structures responsible for synaptic transmission, and with a rapidly developing tissue hypoxia as a consequence of microcirculatory disturbances and a sharp inhibition of the energetic 

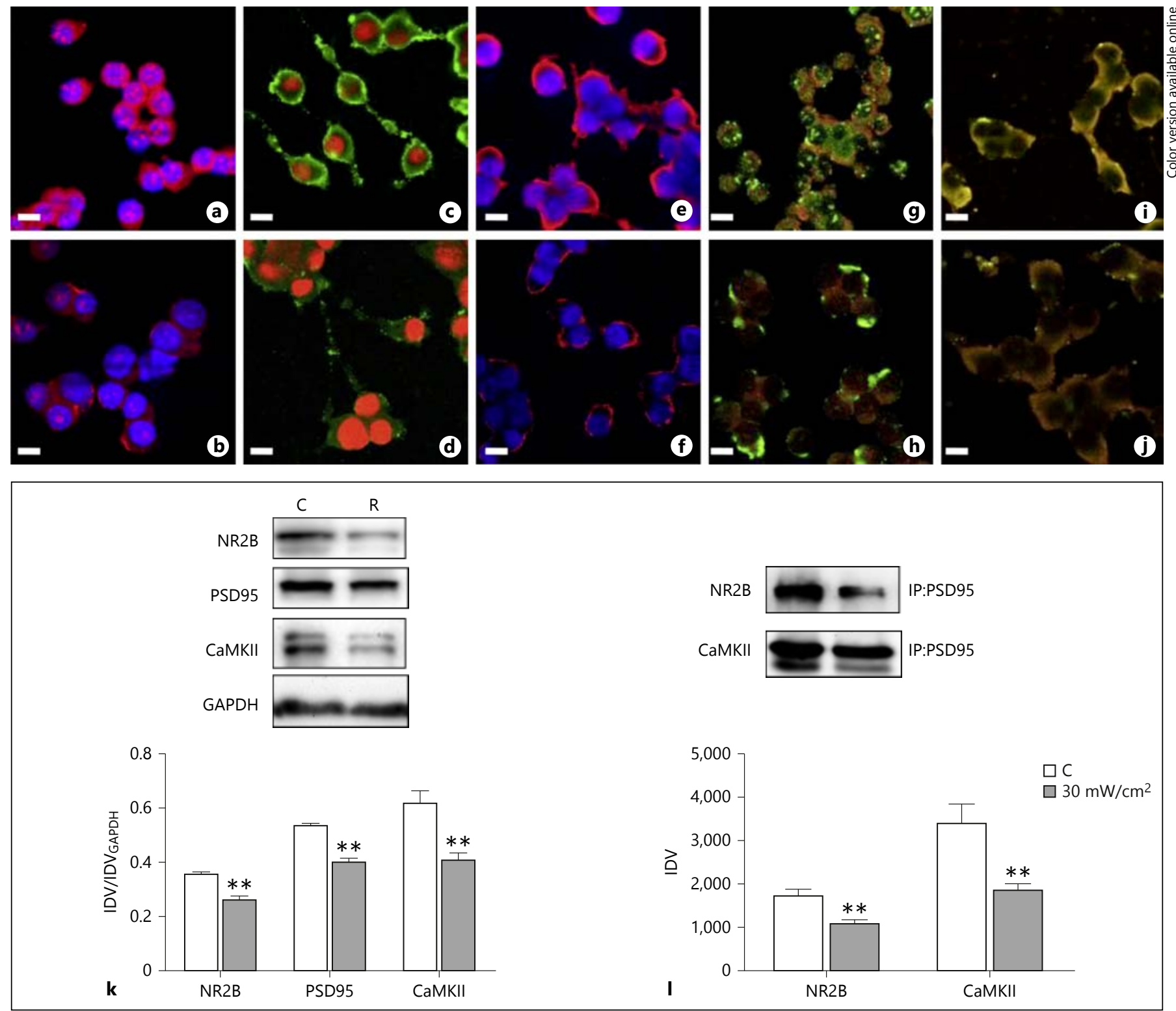

Fig. 5. Effects of $30 \mathrm{~mW} / \mathrm{cm}^{2}$ microwaves on expression levels and co-localization of NR2B, PSD95 and p-CaMKII in PC12 cells. Scale bar $=10 \mu \mathrm{m}$. $\mathbf{a}, \mathbf{b}$ Representative images of NR2B-positive expression from the sham-treated group and $30 \mathrm{~mW} / \mathrm{cm}^{2}$ microwave exposure group are shown as red fluorescence in the cytoplasm of PC12 cells. c, d Representative images of PSD95-positive expression from the sham-treated group and $30 \mathrm{~mW} / \mathrm{cm}^{2}$ microwave exposure group are shown as green fluorescence in the cytoplasm of PC12 cells. e, f Representative images of p-CaMKII-positive expression from the sham-treated group and $30 \mathrm{~mW} / \mathrm{cm}^{2}$ microwave exposure group are shown as red fluorescence in the cytoplasm of PC12 cells. $\mathbf{g}, \mathbf{h}$ Representative images of co-localization of NR2B and PSD95 from the sham-treated group and $30 \mathrm{~mW} / \mathrm{cm}^{2}$ micro- wave exposure group are shown as yellow fluorescence in the cytoplasm of PC12 cells. $\mathbf{i}$, j Representative images of co-localization of PSD95 and p-CaMKII from the sham-treated group and 30 $\mathrm{mW} / \mathrm{cm}^{2}$ microwave exposure group are shown as yellow fluorescence in the cytoplasm of PC12 cells. The nuclei of PC12 cells are stained as red fluorescence by propidium iodide or as blue fluorescence by Hoechest staining. k Representative images and semiquantified data of NR2B, PSD95 and p-CaMKII expression by Western blots. I Representative images and semi-quantified data of coexpression of NR2B and PSD95, PSD95 and p-CaMKII by coimmunoprecipitation. $\mathrm{C}=\mathrm{Control}$ IDV $=$ integrated density value; IP = immunoprecipitation. See online version for colors. 
Fig. 6. Effects of $30 \mathrm{~mW} / \mathrm{cm}^{2}$ microwaves on the binding activity of CREB and DNA in PC12 cells. a Representative images of the binding activity of CREB and DNA by EMSA. 1 = Negative control: no binding band without nuclear proteins; 2, 5 = binding band with nuclear proteins of shamtreated controls at 6 and $24 \mathrm{~h}$, respectively; $3,4=$ binding bands at 6 and $24 \mathrm{~h}$, respectively, following $30 \mathrm{~mW} / \mathrm{cm}^{2}$ microwave radiation; 6 = specific inhibiting reaction: no binding band; 7 = positive control: obvious binding band with nuclear proteins. b Semi-quantified data of the binding activity of CREB and DNA by EMSA. C = Control; IDV = integrated density value.

Fig. 7. Effects of $30 \mathrm{~mW} / \mathrm{cm}^{2}$ microwaves on the expression and phosphorylation of synapsin I in PC12 cells. Scale bar $=20 \mu \mathrm{m}$. a, c, e Representative images of positive expression of synapsin I (a), p-synapsin I $\left(\mathrm{Ser}^{62 / 67}\right.$ c) and $\mathrm{p}$-synapsin I $\left(\mathrm{Ser}^{553}\right.$; e) from the sham-treated group are shown as green fluorescence in the cytoplasm of PC12 cells. $\mathbf{b}, \mathbf{d}, \mathbf{f}$ Representative images of positive expression of synapsin I (b), psynapsin I (Ser $\left.{ }^{62 / 67} ; \mathbf{d}\right)$ and $\mathrm{p}$-synapsin I $\left(\mathrm{Ser}^{553}\right.$; f) from the $30 \mathrm{~mW} / \mathrm{cm}^{2}$ microwave exposure group are shown as green fluorescence in the cytoplasm of PC12 cells. The nuclei of PC12 cells were stained as red fluorescence by propidium iodide. $\mathbf{g}$ Representative images and semi-quantified data of synapsin (SYN) I, p-SYN I (Ser ${ }^{62 / 67}$ ) and p-SYN I $\left(\right.$ Ser $\left.^{553}\right)$ expression by Western blots. 1, 3, 5 = SYN I, p-SYN I (Ser $\left.{ }^{62 / 67}\right)$ and p-SYN I $\left(\mathrm{Ser}^{553}\right)$ expression in sham-treated controls, respectively; 2, 4, $6=$ SYN I, p-SYN I $\left(\operatorname{Ser}^{62 / 67}\right)$ and p-SYN I $\left(\operatorname{Ser}^{553}\right)$ expression $6 \mathrm{~h}$ after microwave exposure. Values represent the mean \pm SEM of 3 samples. ${ }^{*} \mathrm{p}<0.05,{ }^{* *} \mathrm{p}<0.01$, vs. corresponding sham-treated controls (C). See online version for colors.
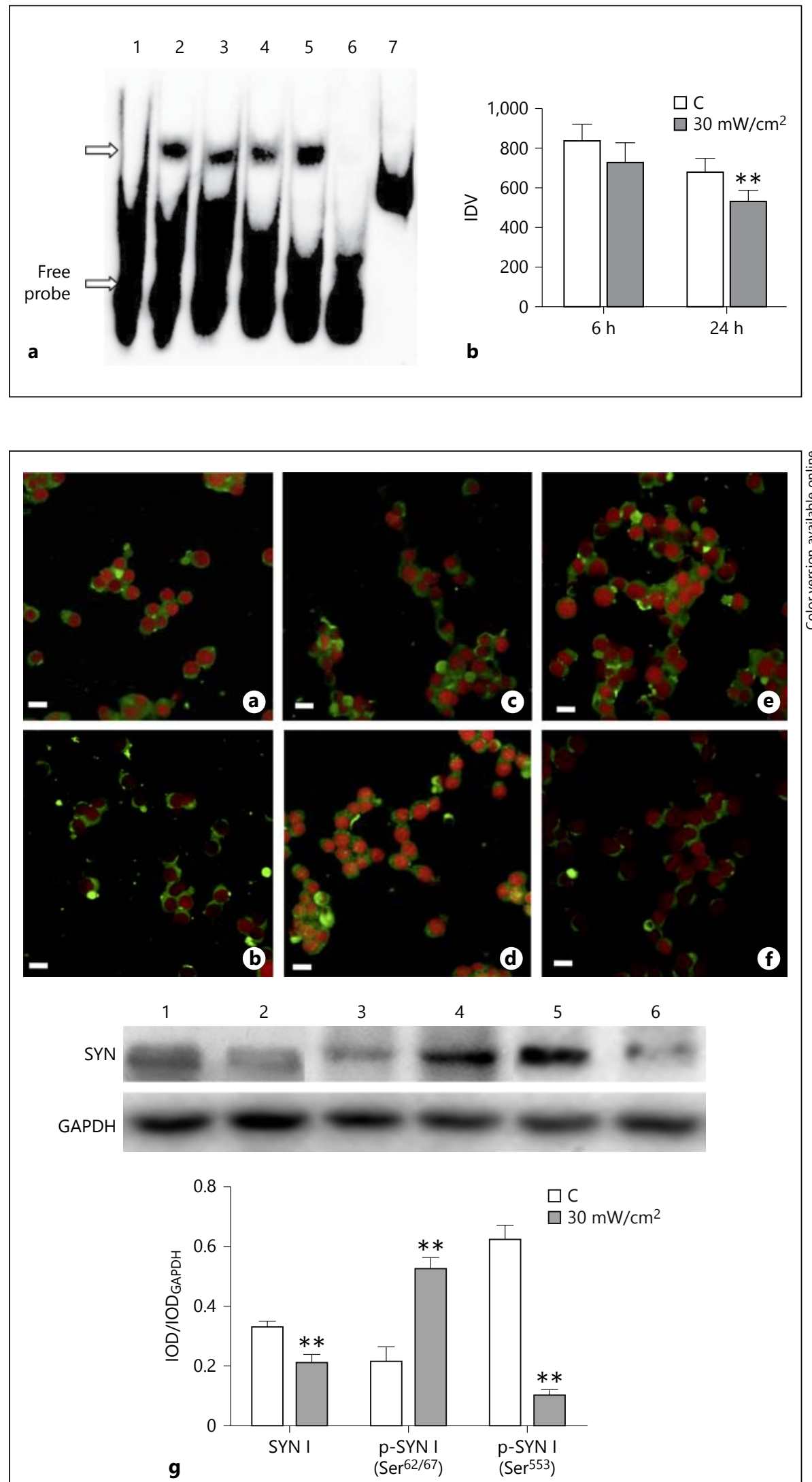
metabolism [19]. In our previous experiment [20] in the hippocampus, we found tissue edema, osteoporosis, different degrees of degeneration and neuronal necrosis, vascular congestion and hemorrhage, and an enlarged perivascular space during the 6 months after $2.5,5$ and $10 \mathrm{~mW} / \mathrm{cm}^{2}$ long-term exposure to microwave radiation. The mitochondria were swollen and malformed, with crista breaks and cavitation. There was no elevation in the temperature of rats. The numbers of Nissl granules were decreased to different extents in the exposure groups and were the most serious in the group exposed to $10 \mathrm{~mW} / \mathrm{cm}^{2}$ radiation.

In this study, hippocampal neurons and PC12 cells were injured, including lesions in mitochondria, rough endoplasmic reticulum and nuclei, following microwave radiation. We, therefore, established an injury animal model and a cell model for microwave radiation with appropriate radiation dosages.

Quantitative analyses of synapses are rarely reported. We found deposits in synaptic vesicles, which suggested that the release of some neurotransmitters may have been disordered as a result of the obstruction of synaptic vesicles docking with the active zone [21]. We also found elongation of the active zone, increased PSD thickness and curvature, and perforation of the synapses. These changes may be involved in postsynaptic adaptive changes made to alleviate the presynaptic injury. In addition, synaptic injury was more serious than that of other organelles following microwave radiation, which indicated that synapses were sensitive to microwave radiation.

Neurotransmitters as messengers are principally released via $\mathrm{Ca}^{2+}$-dependent synaptic vesicle exocytosis, which is an important focus of research in the bioeffects of microwave radiation. Amino acid neurotransmitters play an important role in synaptic transmission, learning and memory; however, there is limited research regarding the effects of microwave radiation on amino acids. In our previous experiment [20], we found a significant increase in four kinds of amino acid neurotransmitter contents in the hippocampus $6 \mathrm{~h}, 14$ days and 2 months following exposure to 2.5 and $5 \mathrm{~mW} / \mathrm{cm}^{2}$ long-term microwave radiation. GABA contents were decreased after $6 \mathrm{~h}$, and Asp and Glu contents were decreased after 14 days and 2 months in the group exposed to $10 \mathrm{~mW} / \mathrm{cm}^{2}$ radiation. In our study, the contents of Asp, Glu and Gly in the hippocampus, and the release of GABA and Gly in PC12 cells, were all decreased following microwave radiation. The decrease in the contents of Glu, a main excitatory amino acid, may indicate that the excitability of hippo-

Microwave-Induced Neuronal Injury campal neurons decreased and that microwaves inhibited this activity. The decrease in GABA and Gly release could arise from the disruption of synaptic vesicles in terms of their docking and fusion with presynaptic membranes, which is in accordance with the injuries of the synaptic structure in the hippocampus.

\section{Abnormality of the NMDAR-PSD95-CaMKII}

Pathway May Contribute to Synaptic Transmission

Impediment following Microwave Radiation

NMDARs are multiheteromers composed of NR1 and NR2 subunits encoded by different genes. NR1 is the functional subunit and the essential component of NMDARs. The NR2 subunit mainly plays a regulatory role and is necessary for the time- and space-regulatory expression of NMDARs [22-24]. The NR2B subunit has been implicated as a principal player in the induction of some forms of LTP, mediating feeding and related physiological functions, learning, memory, pain and synaptic plasticity $[25,26]$. Some studies have suggested that the complex of NR2B with PSD95 is implicated in the regulation of synaptogenesis, synaptic plasticity and the processes of learning and memory [27-29].

In general, NMDARs initially combine with a Glu neurotransmitter, which is released from the presynaptic membrane and opens the NMDAR channels. A large amount of $\mathrm{Ca}^{2+}$ flows into the synaptic cleft, which activates the phosphorylation of calcium/CaMK and some related proteins in the postsynaptic membrane. As the concentration of $\mathrm{Ca}^{2+}$ in the postsynaptic membrane increases, it activates nitric oxide (NO) synthase in the cytoplasm. The secondary messenger, NO, is generated by NO synthase in the metabolic progress. NO enters the presynaptic membrane, which causes the phosphorylation of protein, the influx of $\mathrm{Ca}^{2+}$ and the glycosylation of protein kinase $\mathrm{C}$. It then activates the expression of some early immediate genes (c-fos and c-jun) and transcription factors (CREB). The transcription factors change the expression of nuclear genes, including the subunit gene of NMDARs, and ultimately cause the synthesis of different proteins [30-32].

Experimental data have shown that microwave radiation may induce dysfunction in learning and memory, but little is known about the mechanisms involved. Xu et al. [33] found that GSM 1,800-MHz microwave exposure (SAR of $2.4 \mathrm{~W} / \mathrm{kg}, 15 \mathrm{~min}$ per day for 8 days) resulted in a decrease in the expression of PSD95 and the amplitude of a-amino-3-hydroxy-5-methyl-4-soxazole propionic acid (AMPA) miniature excitatory postsynaptic currents (mEPSCs). However, the frequency of AMPA mEPSCs 
and the amplitude of NMDA mEPSCs did not change in the cultured hippocampal neurons, which may reduce excitatory synaptic activity and the number of excitatory synapses in cultured rat hippocampal neurons. Liboff et al. [34] reported that in 21-day-old rats an extremely low frequency electromagnetic field exposure for 90 days was associated with increases in the concentration of $\mathrm{Ca}^{2+}$, protein kinase $\mathrm{C}$ and cAMP-dependent proteinase activities and calcineurin levels in neurons of the hippocampal zone. Using a ligand binding experiment, the authors found that the binding capability of NMDARs declined and suggested that the electromagnetic field may alter the abnormality of NMDAR function by changing the signal transduction process of $\mathrm{Ca}^{2+}$.

PSD95 is the most abundant scaffolding protein in PSDs and potentially binds many key constituent PSD proteins, such as NMDARs and AMPA receptor complexes, via adhesion molecules and other scaffolding proteins [35-38]. Consistent with its organizing role, PSD95 is one of the most stable proteins at excitatory synapses [38]. In this study, NR1, NR2A, NR2B and PSD95 expression was increased in hippocampal neurons following $10 \mathrm{~mW} / \mathrm{cm}^{2}$ microwave radiation, in accordance with the increase in PSD thickness and elongation of the postsynaptic active zone. After microwave radiation, the decreased contents of Glu in the hippocampus induced the postsynaptic adaptive changes. The increase in PSD95 and NMDARs as the main components of PSD also accelerated the increase in PSD thickness and elongation of the active zone. Furthermore, it activated the NMDAR channels, increasing the concentration of $\mathrm{Ca}^{2+}$ in the postsynaptic membrane [39] and causing neuronal injury through multisignal transduction pathways.

In PC12 cells, we found that NR2B mRNA increased, and there were decreases in the PSD95 mRNA level, the expression levels of NR2B, PSD95 and p-CaMKII, the coexpression of NR2B and PSD95, PSD95 and p-CaMKII, and the binding activity of CREB with DNA following 30 $\mathrm{mW} / \mathrm{cm}^{2}$ microwave radiation. On the one hand, the release of Glu decreased; subsequently, the combination of Glu with NMDARs decreased after microwave radiation, which inhibited the opening of the NMDAR channels and the phosphorylation of CaMKII. On the other hand, the decreased expression of and interactions between NR2B, PSD95 and p-CaMKII resulted in a cell excitement decrease, and the expression and DNA binding activity of CREB was inhibited, which further restrained the expression of nuclear genes such as PSD95 and NMDARs. However, the increase in NR2B mRNA might relate to anoth- er transcription factor. The decrease in cell excitement resulted in the injury of PC12 cells, including lesions of the mitochondria, rough endoplasmic reticulum and nucleus, and could inhibit the expression and activity of the NMDAR-PSD95-CaMKII pathway.

Vaynman et al. [40] reported that brain-derived neurotrophic factor mediates exercise-induced hippocampal plasticity by regulating the mRNA levels of two end products that are important for neural function, CREB and synapsin I. These have the ability to modify neuronal function by affecting gene transcription and synaptic transmission, respectively. A decrease in the binding activity of CREB and DNA in PC12 cells may inhibit the expression of synapsin I nuclear genes, as reflected by the decrease in synapsin I mRNA and protein following 30 $\mathrm{mW} / \mathrm{cm}^{2}$ microwave radiation [41].

Synapsin I has multiple phosphorylation sites. These include site $1\left(\mathrm{Ser}^{9}\right)$ or the PKA/CaMKI/CaMKIV site localized in domain A, sites 2 and 3 correspond to Ser ${ }^{566}$ and $\mathrm{Ser}^{603}$ in domain D CaMKII, sites 4 and 5 (Ser ${ }^{62 / 67}$ ) and sites 6 and $7\left(\mathrm{Ser}^{551} / \mathrm{Ser}^{553}\right)$, which are localized in domain B and phosphorylated by ERK/mitogen-activated protein kinase (MAPK). Sites 6 and 7 are also phosphorylated by cyclin-dependent protein kinases. Site 8 $\left(\mathrm{Tyr}^{301}\right)$ is localized in domain $\mathrm{C}$ and phosphorylated by Src, and site 9 is localized in domain E of synapsin Ia and phosphorylated by the ataxia-telangiectasia mutated kinase [42]. After $30 \mathrm{~mW} / \mathrm{cm}^{2}$ microwave radiation, the phosphorylation of synapsin I increased at $\operatorname{Ser}^{62 / 67}$ and decreased at Ser ${ }^{553}$ in PC12 cells. This may have been induced by the activation of ERK/MAPK and cyclin-dependent protein kinases, which further resulted in the decrease in amino acid release. However, this explanation needs further investigation. At the molecular level, NMDARs interact with signaling modules, which, like the MAPK superfamily, transduce excitatory signals across neurons. In addition, MAPK plays a crucial role in regulating the neurochemistry of NMDARs, their physiological and biochemical/biophysical properties, and their potential role in pathophysiology [43]. Therefore, the inhibition of NMDARs in PC12 cells following microwave radiation might lead to a decrease in the release of amino acids by regulating synapsin I phosphorylation at MAPK sites.

In conclusion, microwave radiation could result in abnormalities in the NMDAR-PSD95-CaMKII pathway, which may contribute to the inhibition of synaptic transmission by influencing synaptic structure, the expression and phosphorylation of synapsin I, and intervening in the release of neurotransmitters to other neurons. 


\section{Acknowledgments}

We are grateful for the kind help of Sa Zhang and Zhi-yi Zhang (National Center of Biomedical Analysis) with EM and laser scanning confocal microscopy, and Assoc. Prof. Chang-yan
Li (Beijing Institute of Radiation Medicine) with EMSA technology. This work was supported by National Science and Technology Major Projects (2008ZXJ09004-019) and the National Natural Science Foundation of China (30900382 and 81172620).

\section{References}

1 Kesari KK, Kumar S, Behari J: Pathophysiology of microwave radiation: effect on rat brain. Appl Biochem Biotechnol 2012;166: 379-388.

$\checkmark 2$ Mortazavi SM, Mahbudi A, Atefi M, Bagheri $>_{13}$ S, Bahaedini N, Besharati A: An old issue and a new look: electromagnetic hypersensitivity caused by radiations emitted by GSM mobile phones. Technol Health Care 2011;19:435443.

-3 Del Vecchio G, Giuliani A, Fernandez M, Mesirca P, Bersani F, Pinto R, Ardoino L, Lovisolo GA, Giardino L, Calza L: Effect of radiofrequency electromagnetic field exposure on in vitro models of neurodegenerative disease. Bioelectromagnetics 2009;30: 564-572.

4 Rebola N, Srikumar BN, Mulle C: Activitydependent synaptic plasticity of NMDA receptors. J Physiol 2010;588:93-99.

5 Cavara NA, Hollmann M: Shuffling the deck anew: how NR3 tweaks NMDA receptor function. Mol Neurobiol 2008;38:16-26.

6 Schrattenholz A, Soskic V: NMDA receptors are not alone: dynamic regulation of NMDA receptor structure and function by neuregulins and transient cholesterol-rich membrane domains leads to disease-specific nuances of glutamate-signalling. Curr Top Med Chem 2006;6:663-686.

7 Lau CG, Zukin RS: NMDA receptor trafficking in synaptic plasticity and neuropsychiatric disorders. Nat Rev Neurosci 2007;8:413426.

8 Swulius MT, Kubota Y, Forest A, Waxham $\mathrm{MN}$ : Structure and composition of the postsynaptic density during development. J Comp Neurol 2010;518:4243-4260.

-9 Moyano S, Frechilla D, Del Rio J: NMDA receptor subunit and CaMKII changes in rat hippocampus induced by acute MDMA treatment: a mechanism for learning impairment. Psychopharmacology (Berl) 2004;173:337345.

10 Sanhueza M, Fernandez-Villalobos G, Stein IS, Kasumova G, Zhang P, Bayer KU, Otmakhov N, Hell JW, Lisman J: Role of the CaMKII/ NMDA receptor complex in the maintenance of synaptic strength. J Neurosci 2011;31: 9170-9178.

11 Xu M, Chandler LJ, Woodward JJ: Ethanol inhibition of recombinant NMDA receptors is not altered by coexpression of CaMKII-alpha or CaMKII-beta. Alcohol 2008;42:425-432.

-12 Gardoni F, Mauceri D, Malinverno M, Polli F, Costa C, Tozzi A, Siliquini S, Picconi B, Cat- tabeni F, Calabresi P, Di Luca M: Decreased NR2B subunit synaptic levels cause impaired long-term potentiation but not long-term depression. J Neurosci 2009;29:669-677.

13 Gardoni F, Polli F, Cattabeni F, Di Luca M: Calcium-calmodulin-dependent protein kinase II phosphorylation modulates PSD-95 binding to NMDA receptors. Eur J Neurosci 2006;24:2694-2704.

14 Bayer KU, De Koninck P, Leonard AS, Hell JW, Schulman H: Interaction with the NMDA receptor locks CaMKII in an active conformation. Nature 2001;411:801-805.

15 Wang H, Peng R, Zhou H, Wang S, Gao Y, Wang L, Yong Z, Zuo H, Zhao L, Dong J, Xu $\mathrm{X}, \mathrm{Su} \mathrm{Z}$ : Impairment of long-term potentiation induction is essential for the disruption of spatial memory after microwave exposure. Int J Radiat Biol 2013;89:1100-1107.

16 Inaloz SS, Dasdag S, Ceviz A, Bilici A: Acceptable radiation leakage of microwave ovens on pregnant and newborn rat brains. Clin Exp Obstet Gynecol 1997;24:215-219.

17 Suvorov NB, Medvedeva MV, Vasilevskii NN, Ur'iash VV, Aleksandrova ZhG: Cumulated biological effects of microwaves and their reflection in behavior, work capacity, growth of body mass and state of brain neurons (in Russian). Radiobiologiia 1989;29: 660-666.

18 Fukui Y, Hoshino K, Inouye M, Kameyama Y: Effects of hyperthermia induced by microwave irradiation on brain development in mice. J Radiat Res 1992;33:1-10.

19 Gaidamkin NA, Davydov BI, Zuev VG, Tikhonchuk VS: Ultrastructure of the cerebral cortex in the rat after the effect of electromagnetic impulse (in Russian). Arkh Anat Gistol Embriol 1988;95:14-18.

20 Zhao L, Peng RY, Wang SM, Wang LF, Gao YB, Dong J, Li X, Su ZT: Relationship between cognition function and hippocampus structure after long-term microwave exposure. Biomed Environ Sci 2012;25:182-188.

21 Wang L, Peng R, Hu X, Gao Y, Wang S, Zhao L, Dong J, Su Z, Xu X, Gao R, Lei C: Abnormality of synaptic vesicular associated proteins in cerebral cortex and hippocampus after microwave exposure. Synapse 2009;63: 1010-1016.

22 Paoletti P, Neyton J: NMDA receptor subunits: function and pharmacology. Curr Opin Pharmacol 2007;7:39-47.

-23 Elfverson M, Linde AM, Le Greves P, Zhou Q, Nyberg F, Johansson T: Neurosteroids allosterically modulate the ion pore of the NMDA receptor consisting of NR1/NR2B but not NR1/NR2A. Biochem Biophys Res Commun 2008;372:305-308.

$24 \mathrm{Xu}$ SJ, Chen Z, Zhu LJ, Shen HQ, Luo JH: Visual recognition memory is related to basic expression level of NMDA receptor NR1/ NR2B subtype in hippocampus and striatum of rats. Acta Pharmacol Sin 2005;26:177-180.

25 Rammes G, Hasenjager A, Sroka-Saidi K, Deussing JM, Parsons CG: Therapeutic significance of NR2B-containing NMDA receptors and mGluR5 metabotropic glutamate receptors in mediating the synaptotoxic effects of beta-amyloid oligomers on long-term potentiation (LTP) in murine hippocampal slices. Neuropharmacology 2011;60:982-990.

26 Varas MM, Perez MF, Ramirez OA, de Barioglio SR: Increased susceptibility to LTP generation and changes in NMDA-NR1 and -NR2B subunits mRNA expression in rat hippocampus after $\mathrm{MCH}$ administration. Peptides 2003;24:1403-1411.

27 Cousins SL, Kenny AV, Stephenson FA: Delineation of additional PSD-95 binding domains within NMDA receptor NR2 subunits reveals differences between NR2A/PSD-95 and NR2B/PSD-95 association. Neuroscience 2009;158:89-95.

28 D'Mello R, Marchand F, Pezet S, McMahon SB, Dickenson AH: Perturbing PSD-95 interactions with NR2B-subtype receptors attenuates spinal nociceptive plasticity and neuropathic pain. Mol Ther 2011;19:1780-1792.

29 Sun QJ, Duan RS, Wang AH, Shang W, Zhang T, Zhang XQ, Chi ZF: Alterations of NR2B and PSD-95 expression in hippocampus of kainic acid-exposed rats with behavioural deficits. Behav Brain Res 2009;201:292-299.

-30 Xia Z, Dudek H, Miranti CK, Greenberg ME: Calcium influx via the NMDA receptor induces immediate early gene transcription by a MAP kinase/ERK-dependent mechanism. J Neurosci 1996;16:5425-5436.

-31 Kass-Simon G, Zompa MA, Scappaticci AA, Zackroff RV, Hufnagel LA: Nucleolar binding of an anti-NMDA receptor antibody in hydra: a non-canonical role for an NMDA receptor protein? J Exp Zool A Ecol Genet Physiol 2009;311:763-775.

32 Park CS, Elgersma Y, Grant SG, Morrison JH: a-Isoform of calcium-calmodulin-dependent protein kinase II and postsynaptic density protein 95 differentially regulate synaptic expression of NR2A- and NR2B-containing Nmethyl-D-aspartate receptors in hippocampus. Neuroscience 2008;151:43-55. 
33 Xu S, Ning W, Xu Z, Zhou S, Chiang H, Luo J: Chronic exposure to GSM $1800-\mathrm{MHz}$ microwaves reduces excitatory synaptic activity in cultured hippocampal neurons. Neurosci Lett 2006;398:253-257.

34 Liboff AR, Cherng S, Jenrow KA, Bull A: Calmodulin-dependent cyclic nucleotide phosphodiesterase activity is altered by $20 \mathrm{mi}-$ croT magnetostatic fields. Bioelectromagnetics 2003;24:32-38.

35 Chao HW, Tsai LY, Lu YL, Lin PY, Huang WH, Chou HJ, Lu WH, Lin HC, Lee PT, Huang YS: Deletion of CPEB3 enhances hippocampus-dependent memory via increasing expressions of PSD95 and NMDA receptors. J Neurosci 2013;33:17008-17022.

36 Chen XB, Nelson CD, Li X, Winters CA, Azzam R, Sousa AA, Leapman RD, Gainer $H$, Sheng M, Reese TS: PSD-95 is required to sustain the molecular organization of the postsynaptic density. J Neurosci 2011;31: 6329-6338.

37 Cheng DM, Hoogenraad CC, Rush J, Ramm E, Schlager MA, Duong DM, Xu P, Wijayawardana SR, Hanfelt J, Nakagawa T: Relative and absolute quantification of postsynaptic density proteome isolated from rat forebrain and cerebellum. Mol Cell Proteomics 2006;5: 1158-1170.

38 Chen XB, Vinade L, Leapman RD, Petersen JD, Nakagawa T, Phillips TM, Sheng M, Reese TS: Mass of the postsynaptic density and enumeration of three key molecules. Proc Natl Acad Sci U S A 2005;102:11551-11556.

39 Wang LF, Peng RY, Hu XJ, Gao YB, Wang SM, Li Y, Wang X, Zhao L, Gao RL, Ma JJ: Influence of microwave radiation on synaptic structure and function of hippocampus in Wistar rats (in Chinese). Zhonghua Lao Dong Wei Sheng Zhi Ye Bing Za Zhi 2007;25:211-214.
40 Vaynman S, Ying Z, Gomez-Pinilla F: Interplay between brain-derived neurotrophic factor and signal transduction modulators in the regulation of the effects of exercise on synaptic-plasticity. Neuroscience 2003;122:647657.

41 Wang LF, Peng RY, Hu XJ, Gao YB, Wang SM, Gao RL, Xu XP, Su ZT, Dong J: Influence of microwave radiation on synapsin I expression in PC12 cells and its mechanism (in Chinese). Xi Bao Yu Fen Zi Mian Yi Xue Za Zhi 2008;24:655-659.

42 Bykhovskaia M: Synapsin regulation of vesicle organization and functional pools. Semin Cell Dev Biol 2011;22:387-392.

43 Haddad JJ: N-methyl-D-aspartate (NMDA) and the regulation of mitogen-activated protein kinase (MAPK) signaling pathways: a revolving neurochemical axis for therapeutic intervention? Prog Neurobiol 2005;77:252-282. 